\title{
Improvement in seed germination by priming treatments in Black nightshade (Solanum nigrum L.)
}

\section{Poovizhi}

Department of Seed Science and Technology, Agricultural College and Research Institute, Madurai- 625104 (Tamil Nadu), India

\section{K Sujatha*}

Department of Seed Science and Technology, Agricultural College and Research Institute, Madurai- 625104 (Tamil Nadu), India

*Corresponding author. Email: sujathakvk@gmail.com

\begin{abstract}
The seeds must be viable and non-dormant for the efficient cultivation of the species of medicinal plants. The seeds of Solanum nigrum possess primary dormancy, which restricts germination. Hence, a laboratory experiment was conducted during 2019 in the Department of Seed Science and Technology, Agricultural College and Research Institute, Madurai, Tamil Nadu. The S. nigrum seeds were primed by soaking in different chemicals viz., $\mathrm{GA}_{3} 100 \mathrm{ppm}$, Thiourea1\%, $\mathrm{KNO}_{3} 0.5 \%$, Succinic acid $100 \mathrm{ppm}$, Ascorbic acid $100 \mathrm{ppm}$, hydro and dry control with soaking durations of $12 \mathrm{~h}$ and seeds were dried under shade to bring back to their original moisture content and used for assessing the seed quality studies. The results revealed that among the different priming treatments Thiourea $1 \%$ recorded higher seed quality parameters viz, speed of germination (5.6), germination (88\%), seedling length $(5.92 \mathrm{~cm})$ and vigour index $(520)$ and the enzyme activity of dehydrogenase ( $0.072 \mathrm{OD}$ value) and lower values of electrical conductivity $\left(0.027 \mathrm{dsm}^{-1}\right)$, amino acids $\left(0.119 \mu \mathrm{\mu g}^{-1}\right)$ and sugars $\left(0.175 \mathrm{\mu gg}^{-1}\right)$. Hence it could be recommended as pre-sowingg seed priming treatment in $S$. nigrum.
\end{abstract}

Keywords: Enzyme activity, Priming, Seed quality, Solanum nigrum.

\section{Article Info}

https://doi.org/10.31018/ jans.vi.2244

Received: March 23, 2020

Revised: April 13, 2020

Accepted: May 3, 2020

\section{How to Cite}

Poovizhi, M. and Sujatha, K. (2020). Improvement in seed germination by priming treatments in Black nightshade (Solanum nigrum L.) Journal of Applied and Natural Science, 12 (2): 84 - 87 https://doi.org/10.31018/ jans.vi.2244

\section{INTRODUCTION}

Solanum nigrum L. (commonly known as 'Black nightshade" in English and 'Makoi' in Hindi) belonging to the family Solanaceae. S. nigrum is an annual herbaceous plant that can grow $50 \mathrm{~cm}$ tall. It is an erect, divaricately branched, unarmed, suffrutescent yearly plant. The economic parts of the plant are leaves, berries, and even the whole herb. The plant contains alkaloids like solamargine, solanigrine, and solasonine. Fruits and juice of $S$. nigrum are used to cure stomach ailments, fevers, and blood impurities, and young shoots to cure skin diseases (Jagatheeswari et al., 2013). The fruits are used as a tonic, laxative, appetite stimulant, and treating asthma .Decoction of stalk, leaves and roots are good source for wounds and cancerous (Pallavi et al., 2014).

Good quality seeds with rapid germination producing synchronized vigorous seedlings, higher seed yield, and productivity are important factors in agriculture. For the propose, seed priming methods are used to improve the qualitative and quantitative parameters of medicinal plants. Seed priming is one of the pre-sowing treatments, which control the hydration level within seeds to allow seedlings to emerge more quality and to help uniform emergence (Taylor and Harman 1990) and also seed priming methods differ depending on crop species and seed and germination conditions (Bush et al., 2000; Khan, 1992; Mc Donald, 2000. It was seen to improve the seedling establishment and enhance the ability of the plant to tolerate subsequent exposure to stresses, resulting in greater survival of the plants (Patade et al.,2011 and 2012) in chilli and jatropha crops. These plants have altered biochemical and physiological responses, thereby leading to improved performance (Patade et al., 2012; Wahid et al., 2017) and also alleviation of dormancy in some crops. Fresh seeds of $S$. nigrum L. were temporarily dormant and germinated at higher alternating temperature. Givelberg et al. (1984) reported that some genotypes of black nightshade may have primary dormancy, and the type of seed dormancy present in S. nigrum is not known. Limited studies are available in S. nigrum. Standardization of dormancy breaking treatments with different chemicals, concentrations and durations are made in $S$. 
nigrum (Keerthana and Sundaralingam (2019). With this background, the present investigation was aimed to study the improvement in the germination percentage of $S$. nigrum (Black Night shade) seeds.

\section{MATERIALS AND METHODS}

The experiment was carried out in the Department of Seed Science and Technology, Agricultural College and Research Institute, Madurai, during the year 2020. Freshly harvested seeds were procured from Pappampatti, Coimbatore. Graded seeds were subjected to priming using various chemicals along with water, $\mathrm{GA}_{3} 100 \mathrm{ppm}$, thiourea $1 \%, \mathrm{KNO}_{3} 0.5 \%$, succinic acid $100 \mathrm{ppm}$, and ascorbic acid $100 \mathrm{ppm}$ with duration of $12 \mathrm{~h}$. Germination test was conducted as per the ISTA (International Seed Testing Association) rules (2016). Observations on seedling length, dry matter (g 10 seedlings-1) and vigour index were calculated (Abdul- Baki and Anderson (1973). The dehydrogenase activity of the seeds was estimated by Kittock and Law (1968). The electrical conductivity of the treated seeds were estimated by a digital conductivity meter. The amount of sugar present in the seed leachate following the method described by Somogyi (1952). The amount of amino acids present in the seed leachate was estimated by Moore and Stein (1948). The experiment was conducted using factorial completely randomized design with three replications, and the statistical analysis was done as per the design of the experiment as suggested by Gomez and Gomez (1984).

\section{RESULTS AND DISCUSSION}

Among the treatments, thiourea $1 \%$ recorded higher speed of germination (5.6), germination $(88 \%)$, seedling length $(5.92 \mathrm{~cm})$ and vigour index (520) followed by ascorbic acid 100ppm recorded 3.5 for speed of germination, $85 \%, 5.27 \mathrm{~cm}$ and 447 for germination, seedling length and vigour index respectively of $S$. nigrum. The control seeds recorded 2.5 for speed of germination, germination $(35 \%)$, seedling length $(3.8 \mathrm{~cm})$ and vigour index (76) (Table 1 ). The most widely used chemical for photosensitive seed is thiourea. It alters the metabolic concentration and nucleic acid metabolism in the seed as a result it increases the germination and seedling vigour. Similar results were reported by Hartmann et al. (1997) in Scentless Mayweed; Arularasu and Sambandamurthi (1999) in Ocimum sanctum L; Revathi (2001) in Phyllanthus amarus; Pandey and Nandi et al., (2000)in Aconitum heterophyllumWall; Shobharani (2018) in medicinal plants and Keerthana and Sundaralingam (2019) in S. nigrum. Increased germination rate and uniformity have been attained due to metabolic repair during imbibition (Bray et al., 1989 and Basra et al., 2003), a buildup of germination enhancing metabolites (Basra et al., 2005). The germination improvement of thiourea was $88 \%$ over control. The germination improvement of thiourea was $88 \%$ over the control. The seeds primed with thiourea $1 \%$ recorded the higher dehydrogenase activity (0.072 OD value) followed by ascorbic acid (0.065OD value). The control seeds recorded lower dehydrogenase activity ( 0.011 OD value). Among the priming treatments, thiourea primed seeds showed lower values of electrical conductivity $\left(0.027 \mathrm{dSm}^{-1}\right)$ compared to control $\left(0.050 \mathrm{dSm}^{-1}\right)$ (Fig. 1). It is possible that the respiratory rate (higher dehydrogenase activity) and preventive role of deteriorative senescence (lower electrical conductivity) might be due to the antioxidant and other biochemically active intermediates present in the thiourea treatments. Butler (2009) and Ventura et al. (2012) noted increased repair activity during priming, which can enhance the seed life span. Hence the priming can have a rejuvenating effect and can overcome damage due to deterioration. Lower values of leachate amino acids recorded in thiourea primed seeds acids $\left(0.119 \mu^{-1}\right)$ and leach-

Table 1. Influence of different priming treatments on speed of germination, Germination (\%), Seedling length, and vigour index in S. nigrum.

\begin{tabular}{|c|c|c|c|c|}
\hline Treatments & $\begin{array}{l}\text { Speed of ger- } \\
\text { mination }\end{array}$ & $\begin{array}{c}\text { Germination } \\
\text { Percentage }(\%)\end{array}$ & $\begin{array}{l}\text { Seedling length } \\
(\mathrm{cm})\end{array}$ & Vigour Index \\
\hline Control & 2.5 & 35 & 3.8 & 76 \\
\hline Hydro & 2.8 & 39 & 4.17 & 141 \\
\hline Ascorbic acid 100 ppm & 3.5 & 85 & 5.27 & 447 \\
\hline Succinic acid 100 ppm & 3 & 48 & 4.31 & 206 \\
\hline $\mathrm{KNO}_{3} 0.1 \%$ & 3 & 58 & 5.07 & 294 \\
\hline Thiourea $1 \%$ & 5.6 & 88 & 5.92 & 520 \\
\hline $\mathrm{GA}_{3} 25 \mathrm{ppm}$ & 3.3 & 62 & 5.15 & 319 \\
\hline Mean & 3.38 & 59.28 & 4.81 & 286 \\
\hline SEd & 0.073 & 1.013 & 0.098 & 6.744 \\
\hline$C D(P=0.05)$ & 0.157 & 2.173 & 0.210 & 14.467 \\
\hline
\end{tabular}




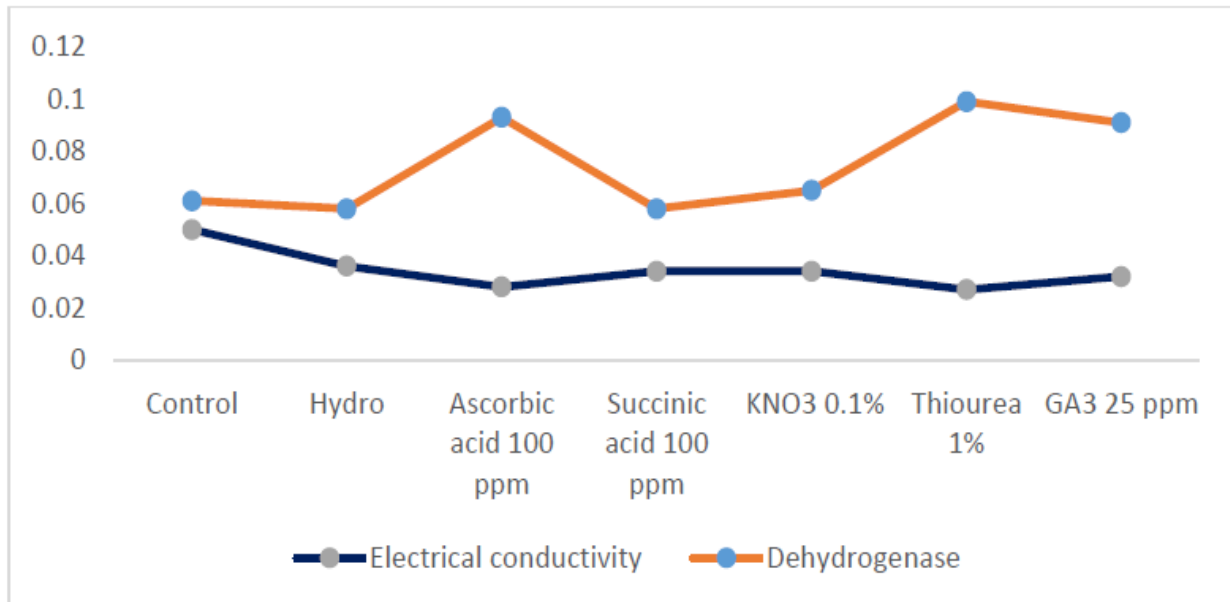

Fig. 1. Effect of different priming treatments on electrical conductivity $\left(d S m^{-1}\right)$ and dehydrogenase activity (OD value).

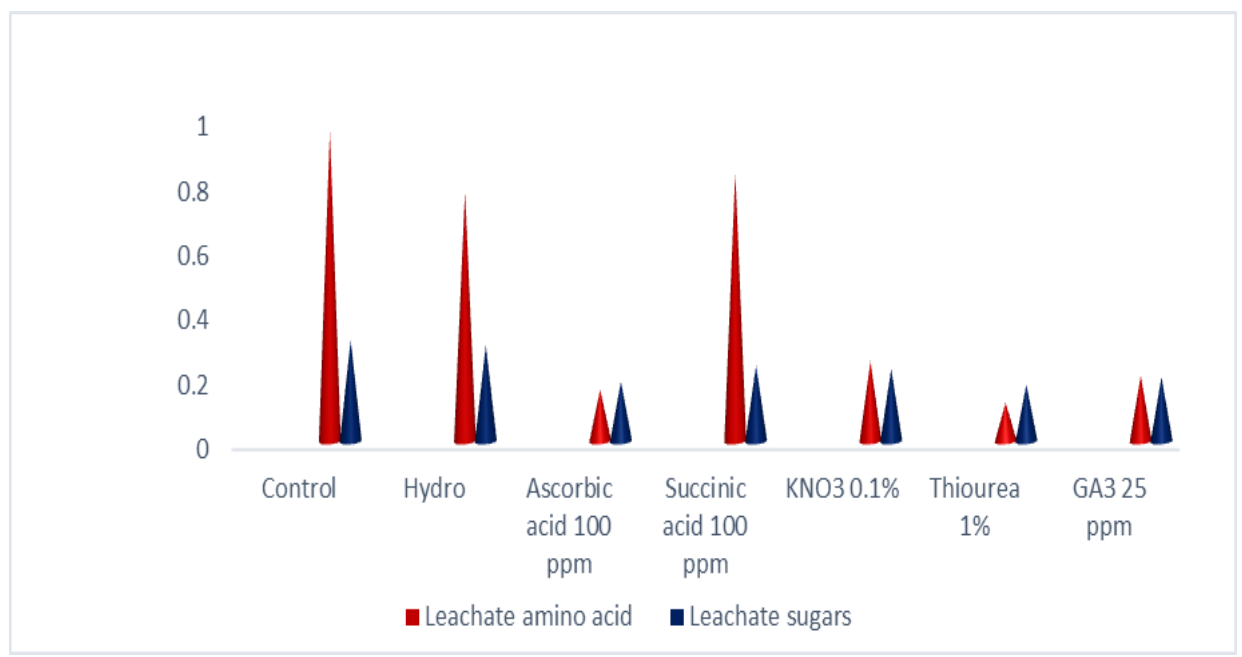

Fig. 2. Effect of different priming treatments on leachate amino acids $\left(\mu g g^{-1}\right)$ and sugars $\left(\mu g g^{-1}\right)$.

ate sugars $\left(0.175 \mu \mathrm{gg}^{-1}\right)$ followed by ascorbic acid 100ppm (0.159 $\mathrm{\mu gg}^{-1}$ for leachate amino acids and $0.184 \mathrm{\mu gg}^{-1}$ for leachate sugars) (Fig. 2). Kelner et al. (1990) and Gao et al., (2008) observed that thiourea is a potent redox scavenger and it has the ability to scavenge multiple Reactive oxygen species (ROS) including superoxide radicle and hydrogen peroxide thereby lowering values of electrical conductivity, leachate amino acids, and sugars.

\section{Conclusion}

It could be concluded that among the various treatments viz., ascorbic acid, succinic acid, $\mathrm{KNO}_{3}$ and $\mathrm{GA}_{3}$ to the seeds of $S$. nigrum, the seeds soaked in thiourea $1 \%$ for about $12 \mathrm{~h}$ improved the germination and it can be recommended as presowing treatment.

\section{ACKNOWLEDGEMENTS}

The authors are very grateful to TNSCST (Tamil Nadu State Council for Science and Technology) -
Student Project Scheme (AS-014) for allocation of budget to carry out the present investigation.

\section{REFERENCES}

1. Abdul-Baki, A.A and Anderson, J.D. (1973). Vigour determination of soybean seeds by multiple criteria. Crop Sci., 13: 630-633. http://dx.doi.org/10.2135/ cropsci1973.0011183X001300060013x.

2. Arularasu, P. and Sambandamurthi, S. (1999). Effect of gibberellic acid, nitrogen and spacing on herbage yield and oil yield in tulsi (Ocimum sanctum L.). South Indian Horticulture., 7(1/6): 370-372.

3. Basra, S. M. A., Ahmad, N., Khan, M. M., Iqbal, N. and Cheema, M. A.(2003) Assessment of cotton seed deterioration during accelerated ageing. Seed Science and Technology., 31(3):531-540.

4. Basra, S.M.A, Farooq, M., Tabassam, R. and Ahmad, N.(2005) Physiological and biochemical aspects of pre-sowing seed treatments in fine rice (Oryza sativa L.). Seed Science and Technology., 33: 623-628. https://doi.org/10.15258/sst.2003.31.3.02.

5. Bray, C. M., Davison, P.A., Ashraf,M. and Taylor,R. M.(1989). Biochemical changes during osmopriming 
of leek seeds. Ann Botany., 36: 185-193.

6. Bush, E.W., Wilson, D., Shepard, D. P., Mccleansc, G. (2000) Enhancement in seed in germination common carpet grass and centipede grass. Hort Science., 3(5):769-770. https://doi.org/10.21273/ HORTSCI.35.4.769

7. Buttler, L.H., Hay,F.R., Ellis,R.H., Smith, R.D and Murray, T.B.(2009). Priming and re drying improve the survival of mature seeds of Digitalis purpurea during storage. Annals of Botany, 103: 1261-1270. http://doi.org/10.1093/aob/mcp059

8. Gao, Q. Wang, G. Sun, Y. and Epstein, I. R.(2008). Simultaneous tracking of sulfur species in the oxidation of thiourea by hydrogen peroxide. The Journal of Physical Chemistry A., 112: 5771-5773. https:// doi.org/10.1021/jp8003932

9. Givelberg, A., Horrowitz, M. and Poljakoff-Mayber, A. (1984). Germination behaviour of Solanum nigrum Seeds. .Journal of Experimental Botany., 35 (4): 588 -598. .https://doi.org/10.1093/jxb/35.4.588

10.Gomez, K. A., Gomez, A. A.(1984). Statistical procedure for Agricultural Research, John Wiley, New York, 690.

11. Hartmann, K., Kroob, C. and Mollwo,A. (1997). Phytochrome-mediated photocontrol of the germination of the Scentless Mayweed, Matricaria inodora L., and its sensitization by nitrate and temperature. Journal of Photochemistry and Photobiology B: Biology., 40 (3):240-252. https://doi.org/10.1016/S1011-1344(97) 00064-X

12.ISTA. International rules for seed testing. (2016) Seed Science and Technology, Zurich, Switzerland.

13.Jagatheeswari, D., Bharathi, T. and Sheik Jahabar, A. H.(2013).Black Night Shade (Solanum nigrum L.) An Updated Overview. International Journal of Pharmaceutical \& Biological Archives., 4(2): 288 - 295.

14. Keerthana, S. and Sundaralingam, K.(2018)An evaluation of thiourea application in breaking dormancy of black nightshade (Solanum nigrum L). International Journal of Agricultural Science and Research., 9 (3): 259-266

15.Kelner, M., Bagnell, R. and Welch, K. (1990). Thiourea react with superoxide radicals to yield a sulfhydryl compound. Explanation for protective effect against paraquat. Journal of Biological Chemistry., 265: 1306-1311.

16.Khan, A. A.(1992). Pre-plant physiological seed conditioning. In: Horticulture Reviews., 14: 131-181.

17.Kittock, D.L and Law, A.G. (1968) Relationship of seedling vigour, respiration and tetrazolium chloride reduction by germination of wheat seeds. Agron. J., 60: $286-288$
18.McDonald, M. B. (2000). Seed priming. Seed technology and its biological basis., 287-325.

19. Moore, S. and Stein, W.H. (1948) Photometric ninhydrin method for use in the ehromatography of amino acids. Journal of Biological Chemistry., 176: $367-$ 388.

20.Pallavi, H., Vishwanath, K., Harish, B., Prashanth. Y. and Thattimani, M. (2014). Seed treatments to break seed dormancy and Standardization of viability test procedure in Abrus precatorious. Journal of Medicinal Plants Research., 8(4): 229-236. DOI: 10.5897/ JMPR2013.5102

21.Pandey, H., Nandi, S., Nadeem, M., and Palni, L. (2000). Chemical stimulation of seed germination in Aconitum heterophyllumWall. and A. balfourii Stapf: important Himalayan species of medicinal value. Seed Science and Technology., 28(1):39-48.

22.Patade, V.Y, Khatri, D. Manoj, K.(2012). Cold tolerance in thiourea primed capsicum seedlings is associated with transcript regulation of stress responsive genes. Molecular Biology Reports., 39:10603-10613. DOI: 10.3923/rjss.2011.125.136.

23.Patade, Y. V., Maya, K. and Zakwan, A.(2011). Seed priming mediated germination improvement and tolerance to subsequent exposure to cold and salt stress in capsicum. Research Journal of Seed Science., 4 (3): 125-136.

24.Revathi, R. (2001). Seed production, testing and storage studies in Phyllanthus amarus (Schum and Thom.). M. Sc. (Ag.) Thesis, Tamil Nadu Agricultural University, Coimbatore.

25.Shobharani, M. (2018). Standardization of seed germination testing procedures and seed germination improvement in medicinal plants .M. Sc. (Ag.) Thesis, Tamil Nadu Agricultural University, Coimbatore.

26.Somogyi, M.(1952). Notes on sugar determination. Journal of biological chemistry., 195: 19-23.

27.Taylor, A.G. and Harman, G.E.(1990). Concepts and technologies of selected seeed treatments. Annual Review of Phytopathology., 28: 321-339. https:// doi.org/10.1146/annurev.py.28.090190.001541.

28.Ventura, L., Dona, M., Macovei, A., Carbonera, D. Buttafava ,A., Mondoni, A and Balestrazzi, A. (2012). Understanding the molecular psth ways associated with seed vogour. Plant physiology and Bio chemistry, 60:196-206. http://doi.org/10.1016/j.plaphy. 2012.07 .031

29.Wahid, A., Basra, S.M.A. and Farooq, M.(2017). Thiourea: A Molecule with Immense Biological Significance for Plants. International Journal of Agriculture \& Biology., 19(4): 911-920. DOI: 10.17957/ IJAB/15.0464 